\title{
New (Other?) Directions in Corporate Social Responsibility
}

\author{
Nicholas Capaldi
}

\begin{abstract}
The purpose of this article is to challenge scholars of corporate social responsibility and CSR officers of private corporations to rethink their subject matter and their approach. The fundamental problem that needs to be addressed in CSR scholarship is whether it is descriptive or normative or something else. I maintain that much of the current literature is inadequately descriptive and philosophically deficient with regard to norms. I suggest a number of additional activities for CSR research (e.g., consumer responsibility) compatible with a morally pluralistic world that is hospitable to a market economy.
\end{abstract}

\section{Introduction}

The purpose of this essay is to challenge scholars of corporate social responsibility and CSR officers of private corporations to rethink their subject matter and their approach. In order to raise this challenge and to provoke further discussion, I have deliberately chosen to overstate my case. With that caveat in mind, let us begin.

\section{The administrative fallacy}

The fundamental problem that needs to be addressed in CSR scholarship is whether it is descriptive or normative or something else (Crane et al. 2008). This is a problem rooted in both philosophy and the history of the social sciences.

The great success of the scientific revolution in the 17th and 18th-centuries gave rise to a new intellectual attitude: the Enlightenment Project (Adorno \& Horkheimer 1990; Carl Becker 1962; Bloom 1987; Capaldi 1998; MacIntyre 1981; McCarthy 1998). The Enlightenment Project asserts that there can be a social science comparable to physical science, that social science can help us explain, predict, and control the social world. In short, there is the belief that there can eventually be a social technology. The dream of a social technological utopia is the common inheritance of liberals, socialists, and Marxists ((Carl Becker 1962), chapter four). Some of us would argue this is delusional and misguided.

It is precisely this belief in a social technology that informs much of the social science disciplines those trained

Correspondence: nick.capaldi@gmail.com

Loyola University, New Orleans, USA in the social sciences and, ultimately, therefore many practitioners in the CSR field. There are academicians ever ready to play the part of Philosopher Kings and Queens. In his critique of what he calls the entrepreneurial society, George Brenkert (long time editor of Business Ethics Quarterly) warns that "instead, then, of a Platonic society, which looked to its philosopher kings, our entrepreneurial society will look to its entrepreneur bosses." ((Brenkert 2002) p. 17). A large part of the hostility of many intellectuals to modern commercial societies is that such societies are not enterprise associations requiring a clerisy (De Jouvenel 1974; Klein 2006; Mises 1975; Nozick 1998; Schumpeter 1975).

“...intellectuals also detested Americanism for a more personal reason. They knew that in an Americanized society, dominated by commercial culture, the place of philosophers and literati was marginal at best. Far from being the dogma by downtrodden peasant, Occidentalism more often reflects the fears and prejudices of urban intellectuals, who feel displaced in a world of mass commerce" ((Buruma \& Margalit 2005), p. 30).

Prior to the modern (Renaissance) period, classical and medieval theorists asserted the existence of a universal teleology. Everything, including the human and social world, was governed by an internal telos (goal). From this perspective, describing and normatizing amount to the same thing. All of that came to an end when modern physics (Descartes, Newton) denied the existence of final causes and therefore denied the existence of teleology in 
the physical world. If social science is supposed to be modeled along the lines of modern physics, then it cannot appeal to objective internal norms or a telos.

It is the Enlightenment Project mentality that obfuscates the distinction between describing and explaining the inherent norms of commercial activity along with an internal critique of when we fail to instantiate those norms as opposed to normative CSR which proscribes, presumably, from a purely external position what participants in commerce should be doing. Where do these external norms originate? Do these external norms reflect a private political agenda or do they reflect a larger social structure? Who has correctly apprehended that larger social structure? Is that structure defensible? How so?

It is not my purpose to denigrate advocacy of any kind or to inhibit political, social, and economic reform. It is my purpose to point out that this is not scholarship. One may use scholarship to support advocacy but advocacy is more than scholarship, and, by itself, scholarship does not entail specific reforms or agendas. To engage in advocacy under the guise of scholarship is to reflect either intellectual confusion or intellectual dishonesty.

There are numerous histories of CSR (Carroll 2008). Relative to my concern with the administrative fallacy, I offer another such history as it emerged in the U.S. (Ryan 2006). The field of CSR was economically and politically liberal because of its origins in business schools and philosophy departments. With regard to business schools, it can be traced back to the University of California-Berkeley in the 1960s, where many of the first leaders of the nascent Business and Society field worked or were trained (Epstein 1999). Research focused on corporations' "social responsibilities" and sought economic reforms to assuage the inequalities perceived to be inherent in capitalism (Jones 1980).

With regard to philosophy, philosophers' traditionally "hostile attitudes" toward business ((Shaw 1996): 490) became immediately evident. They used a specific political agenda to "understand, assess, and perhaps modify the socioeconomic context...that frame[s] the moral choices that confront individuals," often leading to critiques from a Marxist or immoral-market perspective ((Shaw 1996): 496). Others focused the attention of students on corporations' social responsibilities, questioning whether firms should do "more" than maximize profits.

Philosophy has a specific role comprised of two parts, pedagogical and cultural. The pedagogical role is making us self-conscious, aware of our basic presuppositions. This is analysis; it can be taught; and it can be practiced outside of the discipline, the profession and the academy. The cultural role is the fashioning of a narrative that brings the presuppositions of an entire array of cultural practices into some sort of coherent synthesis. This is a role that has been unique to philosophy or to those we identify as great philosophers, even though many of them have played that role outside of the academy.

This second role is not an authoritative role. An individual thinker may choose to do both. However, the legitimacy of the policies derived from the vision in no way follow from the value of the vision. Others can in retrospect appreciate the value and importance and influence of the vision without endorsing the derived policies. We value Aristotle's analysis of the polis, but most of us would choose not to live in one. To engage in this activity is to offer a vision, not an argument, although the vision may contain arguments within it. Identifying presuppositions is different from the application of those presuppositions or the challenging of some of those presuppositions in the light of others. It is a role that acknowledges the freedom of the imagination, the autonomy of choice, and in the contemporary context the goodness or validity of a civil association. It is a role that can never be played by self-alienated and self-proclaimed elites who strive to reveal to others their respective roles and beliefs and actions within an enterprise association, that is, an association with a collective goal to which individual goals are subordinate. Many prominent members of the philosophy profession are so unreflectively hostile to modern commercial societies that they have incapacitated themselves from providing a vision: Rorty, MacIntyre, Blackburn, Derrida, Foucault, to name just a few. A large part of the hostility of many intellectuals to modern commercial societies is that such societies are not enterprise associations requiring a clerisy Hollander (Hollander 2006). Philosophy, for many, is the articulation of a moral vision (an alternative vision) for those hostile to substantive religious communities.

Even so-called empirical research was tainted by a bias. One study claimed that undergraduate business students were overwhelmingly "utilitarian egoists" (Wood et al. 1998), and another that MBA students were egoistic. The assumption in both studies was that "egoism" is of the "subjective" variety, emphasizing maximizing one's subjective view of one's own good in the short term and ignoring the consequences for others. This study, of course, ignores other variants of philosophical egoism. These studies reinforce the assumption that business students, and ultimately business persons, are morally wanting.

The field's most successful assault on free-market thinking is "stakeholder theory," which claims that the corporate executive's job is to balance the needs and desires of all the corporate constituencies (Donaldson \& Preston 1995). That position is contrasted in the literature with "stockholder theory," which generally follows Friedmans (Friedman 1970) position that executives should maximize profits "within the rules of the game." We ignore for the moment whether this is an accurate account of Friedman. What needs to be emphasized is 
the reaction of the business community to stakeholder theory initially and later when business people attempted to apply it in practice. According to the Business Round Table:

[1990] Corporations are chartered to serve both their shareholders and society as a whole. The interests of the shareholders are primarily measured in terms of economic return over time. The interests for others in society (other stakeholders) are defined by their relationship to the corporation.... The thrust of history and law strongly supports the broader view of the directors' responsibility to carefully weigh the interests of all stakeholders as part of their responsibility to the corporation or to the long term interests of its shareholders. ("Corporate Governance and American Competitiveness," March 1990)

[1997] The weakness of the stakeholder model is the absence of an overall objective function which implicitly or explicitly specifies the tradeoffs from expenditures on various items, including each of the firm's stakeholders. This in turn implies that the top managers of such organizations cannot be held accountable for their decisions because without an overall objective function, there is no way to measure and evaluate their performance....it would leave the board with no criterion for resolving conflicts between interests of stockholders and of other stakeholders or among different groups of stakeholders. ("Statement on Corporate Governance," September 1997, pp. 3-4).

Two other things need to be emphasized, and both of them concern how executives are supposed to balance various claims. First, Schumpeter's concept of 'creative destruction' is not only an economic concept calling attention to how entrepreneurship in a dynamic economy constantly changes the economic landscape: what we produce and do not produce; how we produce it; how we organize production, distribution, marketing, financing, etc. It also applies to changes in the social world that reflect changes in the economic world. For example, think of how economic growth and globalization led to the greater participation of women in the workforce. Think again of how that participation has radically altered not only the workplace but the relationship between men and women, family life, etc. Not only have we not caught up to digesting these changes, but we also have to ask ourselves what other changes are percolating or will develop. If so, how do we know we are balancing claims now in a way that will evolve positively in regard to future developments? The answer is we do not know, we cannot know, and there can certainly be conflicting approaches.

Second, taking Archie Carroll's pyramid as our frame of reference, we might want, and I certainly do, to challenge the notion that we live or ever have lived or expect to live in a morally monistic world. Let me suggest that we live in morally pluralistic world (all of past history and current events are my evidence). Let me suggest that this is sometimes a good thing. If all of the foregoing is true, then there is no single way to balance claims, no algorithm that we can discern or teach.

A serious scholarly review of the philosophical literature will reveal that there is no consensus on resolving ethical disputes at the highest level (Solomon 2006). To begin with, it is not only the case that there are significant ethical disagreements about substantive issues. Many if not most of these controversies do not appear to be resolvable through sound rational argument. Again, many of the controversies depend upon different foundational metaphysical commitments. In most metaphysical controversies resolution is possible only through the granting of particular initial premises and rules of evidence. Even when foundational metaphysical issues do not appear to be at stake, the debates turn on different rankings of the good. Resolution does not appear to be feasible without begging the question, arguing in a circle, or engaging in infinite regress. We cannot appeal to consequences without knowing how to rank the impact of different approaches with regard to different ethical interests (liberty, equality, prosperity, security, etc.). Nor can we appeal to preference satisfaction unless one already grants how one will correct preferences and compare rational versus impassioned preferences, as well as calculate the discount rate for preferences over time. Any Appeal to disinterested observers, hypothetical choosers, or hypothetical contractors will not avail either, because if such decision makers are truly disinterested, they will choose nothing. To choose in a particular way, one must already be fitted out with a particular moral sense or thin theory of the good. Intuitions can be met with contrary intuitions. Any particular balancing of claims can be countered with a different way of achieving a balance. In order to appeal for guidance to any account of moral rationality one must already have secured the content for that moral rationality.

\section{Management, marketing, social science and norms}

There is one particular misguided tendency in social science research in general and CSR research in particular to which I wish to call attention. Again, it concerns the seeming inability of some researchers to deal with norms as opposed to facts. I call attention to the following abstract:

Although prior research provides significant evidence that political ideology (i.e. liberal or conservative) can influence an individual's views about gender roles in economic life, little is known about whether these views influence organizations. In this work, we 
theorize as to why conservative (liberal) managers may have higher (lower) rates of gender inequality in the training, promotion, and turnover of their subordinates, relative to moderate managers. We further theorize that conservative (liberal) managers will be less (more) likely to lead their firm's diversity initiatives, relative to moderate managers. Using novel microdata from the legal services industry, we find support for the majority of our arguments (Carnahan \& Greenwood 2016).

Aside from some fuzzy definitions of what it means to be 'conservative' or 'liberal', the article tells us that 'liberal' managers tend to be more accommodating to diversity programs, and it is the opposite for 'conservatives'. Do we need empirical research to tell us this? Isn't this part of what it means in certain contexts to be 'liberal' or 'conservative'? This is not an empirical finding but a matter of definition. This is like conducting a poll to determine if all bachelors are unmarried males! Does this research show us that diversity programs are good or bad and, if so, relative to what criteria? Is this socalled research meant to lead to the recommendation of CSR policy that 'conservative' managers should be fired? Replaced? Sent to sensitivity sessions?

\section{Spontaneous order}

Although I cannot elaborate on it at length here, I want to suggest that the social world has to be understood in Hayekian terms. The social world is neither a mechanism nor organic. It is historical and evolving. Within it, one can discern two kinds of 'order': made order and spontaneous order. 'Made order' organizations exhibit exogenous order. This means that an outside force imposes order upon an organization. Such order can refer to the purpose or telos that defines the made order. This is exogenous order because the purpose involved is independent of the order, as opposed to being internal to or immanent within the order. 'Spontaneous orders' by contrast exhibit endogenous order; they do not have an external purpose. Neither do they have a built-in telos.

Examples of spontaneous order include - the economy or market order, which Hayek describes as a discovery procedure; the common law legal system, which leads to the discovery of rules immanent within the social practice; the entire social or extended order, which in Wittgensteinian fashion allows initiate learners to become master linguistic practitioners by initiating them into our shared form of life.

No amount of research will enable us to anticipate, reconcile conflicts within, or plan construction of "a rational economic order" (Hayek 1945). In order to do so, we would need (1) perfect knowledge on the part of economic planners, (2) the ability to define, without reference to the understandings of individual economic actors and their contexts, an objective hierarchy of preferences, and (3) the ability to determine the relative values of all means and ends available to the planner(s). The complex claim to perfect knowledge includes within it a claim to know both the appropriate arrangement of all of that knowledge, and the relationship between any two pieces of knowledge, such that it is possible to derive, based upon this knowledge, all of the possible equilibrium outcomes for any set of inputs and possible outputs. The question of relevance is tied to metaphysics. Only if the structure of the world is accurately mirrored in the rules of logical deduction is it conceivable that any single mind or group of minds could possibly know what knowledge is and is not relevant to a given plan. In addition, the totality of possible outcomes of the different uses that we might make of these inputs would have to be deducible from the nature of the inputs themselves. Once we know the properties of the individual inputs, the properties of all possible combinations of inputs are deducible as well, at least in principle. The second requirement of constructing a rational economic order is the ability to define, without reference to the understandings of individual economic actors and their contexts, an objective hierarchy of preferences. This requires calculation based not only on a given system of preferences, but also on the possibility of rationally deducing the correct course of action from the conditions under which planning must take place. The first dimension of this requirement amounts to the assumption of stable, transitive preferences, which are articulable in full and in advance of choice and action and which are not affected by the particular circumstances of individual agents. Finally, we would need the ability to determine the relative values of all means and ends available to the planner in the absence of market institutions and processes. As should be obvious, this also requires that the order in question be understood as a teleocratic order, within which there exists agreement about who has authority to decide in individual cases what course of action the members will pursue. Given this information, it is possible in principle to know which ends are most valuable and to decide which means to use in pursuit of those ends. Of course, none of this is possible.

\section{Consumer responsibility}

The very semantics of the expression CSR carries with it the presumption that corporations have responsibilities, most especially to consumers but to others as well. What about the responsibilities of consumers? A quick search of the category consumer responsibility brings up a whole host of articles on, you guessed it, what corporations owe to consumers or how consumers view CSR. It is almost impossible to find much literature of what we should expect from consumers themselves. The only 
exception seems to be a few articles on how consumers can contribute to social policies of dealing with pollution or private investment. This raises two questions: First, is there a need for the category of consumer responsibility? Second, if the answer to the previous question is yes, then why is there so little work on this issue?

I suggest that the need for the category of consumer responsibility is important. In order to understand this, let us look at the concept of the Technological Project (Capaldi 2004), the philosophical transition from the view that humanity should conform to the natural order to the view that humanity transforms nature to suit human convenience, or in Descartes' words that we are here to make ourselves the masters and possessors of nature. It is the Technological Project in conjunction with the market economy that has led to the creation of products and services (Schumpeter's creative destruction) that have transformed both the physical and social world to such an extent that in an age of globalization we now divide the world into developed and developing economies. Add to this the humor associated with stories about older people not knowing how to use the latest technology. In short, we have a huge problem of consumers confronted with products, services, and choices for which they seem ill equipped. Are there consumers who do not know how to use products responsibly? If so, whose responsibility is it to deal with this problem?

There are several immediate responses designed to defuse this category. First, it will be argued that the Technological Project is itself at fault and that humanity should embrace the GAIA world view and cease and desist immediately from using the products and services of the Technological Project. I do not think this is going to happen because (a) there are serious intellectual problems with the GAIA hypothesis, (b) we need the Technological Project to promote awareness of environmental issues, and (c) most especially it is too late to reject the Technological Project because modernity is committed to the faith in technology - that is, we assume and act on the assumption that future technology will solve the problems created by the older technology. So, for example, the creation of driverless cars will enable us to overcome the irresponsible driving habits of some drivers. This will, in turn, create a new set of problems - e.g., the malfunction of computers that direct such cars. A deep look into the modern world will reveal that it is too late to go back. There is a significant difference between responsible engagement with the environment and a wholesale rejection of the Technological Project.

A second immediate response is, as usual, to (a) see consumers as passive products of their environment and (b) shift the responsibility to corporations, that is, more CSR. Companies should be required to provide more information on products or print more and larger warning labels or sponsor commercials warning about the misuse of products. The clear difficulty with this solution, other than the fact that it has not seemed to be effective, is that we are all on information overload such that more information being produced leads to less information being digested. We can add to this that many consumers are fully aware of the dangers of misusing a product but do so anyway. There is always the American version of CSR of allowing the victims and even the perpetrators of the deliberate misuse of products to sue the company that produces the product. For example, there are numerous examples of U.S. juries imposing damages on companies even when those companies place warning labels on products and go so far as to mechanically inhibit misuse (and the user disables the safety device)! This not only leads to higher insurance costs and thereby imposing additional costs on other consumers but to removing valuable products from the market place.

The most serious objection to these proposed remedies is that they create a moral hazard. The Technological Project has made the world better but more complicated. Can we or should we expect the government and commercial organizations or private firms alone to save us from ourselves? Isn't it time to focus on both educating consumers and demanding more of them in exchange? Are there cases where it is of vital importance to place the burden on the consumer?

\section{Consumers and medical technology: a case in point}

There are many experimental pharmaceutical products and technologies that could conceivably save or improve lives. These products do not at present help everyone and in some cases pose considerable risk. That is why these medical technologies are still in various stages of development and testing.

Who should decide whether or not to employ these experimental products? Doctors? The government? Pharmaceutical CSR personnel? Might it not make more sense to have patients accept final responsibility for deciding on the use of these products? Would this not also be a voluntary benefit to experimenters?

\section{The economics of CSR social transaction costs}

Every firm deals with political and social transaction costs. Political transaction costs are one reason firms, and even whole industries, employ lobbyists. CSR is an example of a social transaction cost. CSR in this context means serving social interests without direct remuneration but which is consistent with and indirectly serves long-term investor value. There is another reason to take this seriously, namely, it often obfuscates the role of management, which is to look at a macro-context that includes more than markets. Most of the CSR literature 
fails to address the economic question of how we measure the value of CSR as opposed to the loss of resources that could have been used for other purposes, including charitable contributions by shareholders. If there is need for an empirical study it should be to determine in some fashion whether addressing social issues is done better directly by Firms or by private philanthropy. This is one issue that contrasts U.S. approaches from E.U. approaches. We should also mention that in the U.S. we have CSR corporate officers intently focused on elaborating procedures to safeguard everyone but especially the firm from legal action either on the part of the government or from frivolous law suits.

\section{Turning the tables}

CSR as traditionally understood operates in two areas: (1) reforming the work place and (2) helping address larger social issues that are not limited to the larger economic and workplace environment.

Let us address the second area first. Most of us assume that CSR goes in only one direction, namely, what firms can do for non-profits as defined by the non-profit industry (CSR scholars and others). On the contrary, should we consider the extent to which business leaders can, may, and should, have a vital role in formulating public policy or reforming non-profits such as universities? To be asked to contribute to the resolution of larger social issues implies participating in the debate as to what exactly those issues are, how the issues are to be diagnosed, and how to prescribe for them. Might business leaders sometimes be in a better position to contribute to that discussion than academics?

Those predisposed to be hostile to markets see CSR as a way of shifting the costs of social policy to the private sector in the face of tax payer rebellion. Often, they assume that they personally will determine the CSR policies and that commercial firms will then foot the bill. Might we argue that what we really need is for the business community to become more actively involved in defining social problems and helping in formulating and implementing remedies. Might the business community as a form of CSR advocate defunding universities that promote ignorance and hostility to markets? Might it seek (as is apparently the case now) to review universities and other educational and research institutions from the point of view of a business? Specifically, what are the objectives, how are they pursued, what are the costs and benefits, rating teachers and scholars on their productivity? In short, why assume that academicians are the best judge of the academic world? After all, academics assume they are the best judge of the commercial world as well as everything else. Short of the appeal to the Enlightenment Project and social technology expertise, I do not see how academics can respond to this question in the affirmative.

With regard to the first area, CSR in the internal operation of the firm, should firms educate employees and their families in why business operates the way it does in a market economy? Should they insist on hiring MBA's only if they have completed a program that is promarket and pro-growth? Should they educate them (and give money to business schools) to explain the evils of corruption and of crony capitalism/socialism?

Another suggestion is to encourage firms to encourage directors, employees, and shareholders to contribute to philanthropies or non-profits that focus exclusively on addressing social problems. Rather than the firm's money and human capital, which might be focused on producing profitable products and services, we encourage the development of spiritual capital on the part of individuals to contribute their own personal money, voluntary free time, and personal expertise to both addressing social issues and expanding the productivity of the market economy. We do not have to share the same ideology to contribute to this. We do not need to detract from a firm's competitive position to do this.

Something close to what I have in mind has been identified by Tierney (Tierney 2006).

"...to a new generation of entrepreneurs, there's no conflict between capitalism and compassion.... The movement's philosopher is John Mackey, the cofounder of Whole Foods. Mackey is a passionate environmentalist, an advocate of animal rights, a promoter of sustainable development - and a selfproclaimed libertarian....'Corporations are lifting billions of people out of poverty', he says. 'Why are they so hated?' Mackey's answer is that capitalism has a branding problem: its practitioners are experts at marketing everything except their own system.... Mackey....thinks that socially conscious companies like Whole Foods have flourished because their founders, employees and customers want a corporation to have grander goals than enriching shareholders....Before taking the company public, he told investors that he was going to devote 5 percent of the profits to philanthropy, so they can't complain now that he's robbing them....It's smart of Google's founders to try using capitalist tools to save the planet; the market's discipline should keep their philanthropy from backing too many lost causes."

\section{Imaginative CSR in the developing world}

Multi-national firms can co-ordinate efforts to expose and oppose corruption. They can publicize research already being conducted by investment banks on which countries have leaders who are promoting growth and which are 
not. We should calculate the costs in human suffering imposed by delays in implementing the true market economy, and identify individuals and groups facilitating and advocating the delay. For example, we could also make a list of the 10 worst CSR programs engaging in cosmetics not substance (e.g., Starbucks, Body Shop, etc.). There is a lot more to be done.

\section{Competing interests}

The author declares that he has no competing interests.

\section{Acknowledgements}

The author wishes to thank the following for their help: Tibor Machan, Lori Verstegen Ryan, Alexei Marcoux, Eugene Heath, Ian Maitland, Nadia Nedzel, and Walter Block. Thanks also to Samuel Idowu and Rene Schmidpeter for their help in creating the Global Corporate Governance Institute.

Received: 30 March 2016 Accepted: 14 April 2016

Published: 5 July 2016

\section{References}

Adorno, T. W., \& Horkheimer, M. (1990). Dialectic of the Enlightenment. J. Cumming (trans.). New York: Continuum.

Bloom, A. (1987). The Closing of the American Mind. New York: Simon \& Schuster. Brenkert, G. (2002). Entrepreneurship, Ethics, and the Good Society (Ruffin Series in Business Ethics. Society of Business Ethics).

Buruma, I., \& Margalit, A. (2005). Occidentalism. The West in the Eyes of its Enemies. London: Penguin.

Capaldi, N. (1998). The enlightenment project in the analytic conversation. Dordrecht: Kluwer Academic Publishers, Philosophical Studies in Contemporary Culture.

Capaldi, N. (2004). The ethical foundations of free market societies. The Journal of Private Enterprise, XX(1), 30-54.

Carl Becker, C. (1962). The Heavenly City of the 18th-Century Philosophers. New Haven: Yale University Press.

Carnahan, S., \& Greenwood, B. (2016). Managers' Political Ideology and Gender Inequality within Organizations. Social Science Research Network.

Carroll, A. (2008). A History of Corporate Social Responsibility: Concepts and Practices. In A. Crane, A. McWilliams, D. Matten, J. Moon, \& D. Siegel (Eds.), The Oxford Handbook of Corporate Social Responsibility. Oxford: Oxford University Press.

Crane, A., McWilliams, A., Matten, D., Moon, J., \& Siegel, D. (2008). The Oxford Handbook of Corporate Social Responsibility. Oxford: Oxford University Press.

De Jouvenel, B. (1974). The Treatment of Capitalism by Continental Intellectuals. In F. A. Hayek (Ed.), Capitalism and the Historians. Chicago: Universirty of Chicago Press.

Donaldson, T., \& Preston, L. E. (1995). The stakeholder theory of the corporation: Concepts, evidence, implications. Academy of Management Review, 20, 65-91.

Epstein, E. M. (1999). The continuing quest for accountable, ethical, and humane corporate capitalism. Business \& Society, 38, 253-267.

Friedman, M. (1970). The social responsibility of business is to increase its profits (pp. 32-33). New York: Times Magazine.

Hayek, F. (1945). The use of knowledge in society. The American Economic Review, 35(4), 519-530.

Hollander, P. (2006). Political Pilgrims: Western Intellectuals in Search of the Good Society. New York: Transaction books.

Jones, T. M. (1980). Corporate social responsibility revisited, redefined. California Management Review, 22(3), 59-67.

Klein, P. (2006). Why Economists Still Support Socialism. Mises Daily Article. Maclntyre, A. (1981). After Virtue. Notre Dame: University of Notre Dame Press.

McCarthy, J. (Ed.). (1998). Modern Enlightenment and the Rule of Reason. Washington, D.C.: Catholic University of America Press.

Mises, L. (1975). The Anti-Capitalist Mentality. Auburn: Mises Institute.

Nozick, R. (1998). Why Do Intellectuals Oppose Capitalism? Washington, D.C.: Cato Policy Report.

Ryan, L. V. (2006). Foundation and form of the field of business ethics. Journal of Private Enterprise, XXI(2), 34-49.

Schumpeter, J. (1975). Capitalism, Socialism, and Democracy. New York: Harper.
Shaw, W. H. (1996). Business ethics today: A survey. Journal of Business Ethics, 15, 489-500.

Solomon, D. (2006). Domestic disarray and imperial ambition: contemporary applied ethics and the prospects for global bioethics. In H. T. Engelhardt (Ed.), Global Bioethics. Salem: Ma. Scrivener.

Tierney, J. (2006). Capitalism with a Heart. New York Times.

Wood, J. A., Longenecker, J. G., McKinney, J. A., \& Moore, C. W. (1998). Ethical attitudes of students and business professionals: A study of moral reasoning. Journal of Business Ethics, 7, 249-257.

\section{Submit your manuscript to a SpringerOpen ${ }^{\mathcal{O}}$ journal and benefit from:}

- Convenient online submission

- Rigorous peer review

- Immediate publication on acceptance

- Open access: articles freely available online

- High visibility within the field

- Retaining the copyright to your article

Submit your next manuscript at springeropen.com 